\title{
UDP-N-acetylglucosamine transferase and glutamine: fructose 6-phosphate amidotransferase activities in insulin-sensitive tissues
}

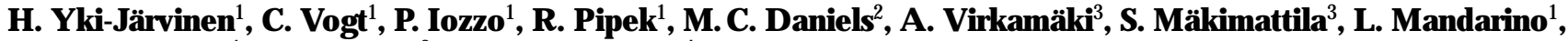 \\ R.A . D efronzo ${ }^{1}$, D. M cClain ${ }^{2}$, W. K. G ottschalk ${ }^{4}$ \\ ${ }^{1}$ The U niversity of Texas H ealth Science Center at San A ntonio, San A ntonio, Texas, U SA \\ ${ }^{2}$ The U niversity of M ississippi M edical Center and Veterans A dministration M edical Center, Jackson, M ississippi, U SA \\ ${ }^{3}$ The $\mathrm{U}$ niversity of $\mathrm{H}$ elsinki, D epartment of M edicine, $\mathrm{H}$ elsinki, Finland \\ ${ }^{4} \mathrm{G}$ laxo Wellcome R esearch and D evelopment, R esearch Triangle Park, N orth Carolina, U SA
}

Summary Glutamine:fructose 6-phosphate amidotransferase (GFA) is rate-limiting for hexosamine biosynthesis, while a UDP-GICNA c $\beta$-N-acetylglucosaminyltransferase ( $0-G$ IcN A c transferase) catalyses final $\mathrm{O}$-linked attachment of G ICNA c to serine and threonine residues on intracellular proteins. Increased activity of the hexosamine pathway is a putative mediator of glucose-induced insulin resistance but the mechanisms are unclear. We determined whether O-G IcN A c transferase is found in insulin-sensitive tissues and compared its activity to that of GFA in rat tissues. We also determined whether non-insulin-dependent diabetes mellitus (NIDDM) or acute hyperinsulinaemia alters O-GICN A c transferase activity in human skeletal muscle. O-GICNA c transferase was measured using ${ }^{3} \mathrm{H}-U D P-G I C N A C$ and a synthetic cationic peptide substrate containing serine and threonine residues, and GFA was determined by measuring a fluorescent derivative of $\mathrm{GICN} 6 \mathrm{P}$ by HPLC. O-GICNA c transferase activities were 2-4 fold higher in skeletal muscles and the heart than in the liver, which had the lowest activity, while GFA activity was 14-36-fold higher in submandibular gland and 5-18 fold higher in the liver than in skeletal muscles or the heart. In patients with NIDDM $(n=11)$, basal $0-G$ IcNA c transferase in skeletal muscle averaged $3.8 \pm 0.3 \mathrm{nmol} / \mathrm{mg} \cdot \mathrm{min}$, which was not different from that in normal subjects ( $3.3 \pm 0.4$ $\mathrm{nmol} / \mathrm{mg} \cdot \mathrm{min})$. A 180-min intravenous insulin infusion ( $\left.40 \mathrm{mU} / \mathrm{m}^{2} \cdot \mathrm{min}\right)$ did not change muscle 0 -G Ic$N$ A c transferase activity in either group. We conclude that O-G IcN A c transferase is widely distributed in insulin-sensitive tissues in the rat and is also found in human skeletal muscle. These findings suggest the possibility that $\mathrm{O}$-linked glycosylation of intracellular proteins is involved in mediating glucose toxicity. 0 G IcNA c transferase does not, however, appear to be regulated by either NIDDM or acute hyperinsulinaemia, suggesting that mass action effects determine the extent of $\mathrm{O}$-linked glycosylation under hyperglycaemic conditions. [D iabetologia (1997) 40: 76-81]

Keywords Hexosamines, insulin, glucose, diabetes mellitus.
Chronic hyperglycaemia or "glucose toxicity" is a major cause of insulin resistance in patients with insulin-dependent (IDDM) and non-insulin-dependent

Corresponding author: H. Y ki-Järvinen, M.D., The U niversity of Texas Health Science Center at San A ntonio, D epartment of Medicine, Division of Diabetes, 7703 Floyd Curl Drive, San A ntonio, Texas 78284, U SA

A bbreviations: IDDM, Insulin-dependent diabetes mellitus; NIDDM, non-insulin-dependent diabetes mellitus; GFA, glutamine:fructose 6-phosphate amidotransferase; GICN6P, glucosamine 6-phosphate; U DP-G ICNA C, U D P-N-acetyl-glucosamine; O-G IcN A c transferease, U D P-G IcNA c $\beta$-N -acetylglucosaminyltransferase; O PA , 0 -phthaldialdehyde; G alN A C, $\mathrm{N}$-acetyl-galactosamine
(NID D M ) diabetes mellitus [1-3]. Studies performed in rat adipocytes have suggested that overactivity of the hexosamine pathway may contribute to glucose induced insulin resistance [4]. G lutamine: fructose 6phosphate amidotransferase (G FA ) catalyses the formation of glucosamine 6-phosphate (GICN 6P) from fructose 6-phosphate and glutamine [5]. GICN 6P is then converted via a series of enzymatic steps to U D P-N-acetyl-glucosamine (U D P-G ICNA C) [6]. Transgenic mice overexpressing GFA in skeletal muscle are insulin resistant [7]. Hyperglycaemia increases G FA activity in cultured human muscle cells [8] and is also associated with increased GFA activity in human skeletal muscle in patients with NIDDM 
[9]. Moreover, streptozotocin-induced diabetes and acute hyperglycaemia are accompanied by increased levels of hexosamine metabolites including UDPGICNA C, in skeletal muscle [10]. In the rat liver, UDP-GICNA C is subsequently $\mathrm{O}$-linked to serine and threonine residues on intracellular proteins via a U D P-N-G IcN A c $\beta$ - $N$-acetylglucosaminyltransferase (O-G IcN A c transferase) [11]. This enzyme was purified from rat liver and was shown to have an extremely high affinity for UDP-GICNA C $\left(K_{m} 545\right.$ $\mathrm{nmol} / \mathrm{l})$. In rat liver, the enzyme exists as a heterotrimer complex with two $\alpha$-subunits of $110 \mathrm{kDa}$ and one $\beta$-subunit of $78 \mathrm{kD}$ a [11]. I t has been suggested, based on the multimeric state and large size of the enzyme, that its activity may be regulated within the cell [11]. Whether the enzyme exists in insulin-sensitive tissues such as in skeletal muscle, heart or adipose tissue is currently unknown. The presence of this enzyme is a prerequisite for the hypothesis that cytosolic 0 -linked glycosylation of one or several proteins is coupled to induction of a defect in the translocation of the insulin-sensitive glucose transporter GLUT4 [12]. The present studies were undertaken to determine if $0-G$ IcN A c transferase activity is found in insulin-sensitive rat or human tissues, and if so how its activity is correlated with that of G FA. We also determined whether O-GICNA c transferase is altered by NIDDM or insulin in vivo.

\section{Subjects, materials and methods}

\section{Experimental design}

A nimals. O vernight fasted male Sprague-D awley rats weighing 200-300 g, were anaesthetized by sodium pentobarbital $(50 \mathrm{mg} / \mathrm{kg}$ body weight i. p.) and the tissues (submandibular gland, epididymal fat, soleus, gastrocnemius, heart and liver) were rapidly removed by freeze-clamping in situ with aluminum tongs precooled in liquid nitrogen, and stored in liquid nitrogen until assay of O-G ICNA c transferase or GFA activity. These studies were approved by the Institutional A nimal Care and U se Committee of the UTHSCSA .

H uman studies. Eleven patients with NID D M [body mass in$\operatorname{dex}\left(B\right.$ MI) $31 \pm 1 \mathrm{~kg} / \mathrm{m}^{2}$, seven women, four men, fasting plasma glucose $9.1 \pm 0.6 \mathrm{mmol} / \mathrm{l}$, fasting $C$-peptide $2.7 \pm 0.3 \mathrm{nmol} / \mathrm{l}$, glycosylated haemoglobin $\left(\mathrm{HbA}_{1 \mathrm{C}}\right) 8.0 \pm 0.7 \%$ ] and eight normal subjects [BMI $29 \pm 1 \mathrm{~kg} / \mathrm{m}^{2}$, four women, four men, fasting plasma glucose $5.3 \pm 0.1 \mathrm{mmol} / \mathrm{l}$, fasting C-peptide $2.2 \pm 0.4 \mathrm{nmol} / \mathrm{l}, \mathrm{HbA}_{1 \mathrm{c}} 4.7 \pm 0.1 \%$ ] volunteered for the studies. A fter written informed consent was obtained, all subjects were physically examined and a 12-lead electrocardiogram was recorded. B lood was drawn for haematocrit, liver function tests, electrolytes, total protein and albumin, serum $C$-reactive protein and creatinine. A urine pregnancy test was performed in the females to exclude pregnancy. A ll subjects had a normal physical examination, electrocardiogram and blood tests. A fter 3 days on a weight-maintaining diet containing at least $200 \mathrm{~g}$ of carbohydrate per day, a 2-h oral glucose tolerance test [13] was performed to exclude patients with impaired glucose tolerance.
The patients with NIDDM were treated with sulphonylureas. The medications were discontinued for 2 days before the study. Informed consent was obtained after the purpose, nature and potential risks were explained to the subjects. The experimental protocol was approved by the institutional review board of the $\mathrm{U}$ niversity of Texas $\mathrm{H}$ ealth Science Center at San A ntonio.

In each subject, insulin sensitivity was measured using the euglycaemic insulin clamp technique (insulin infusion rate $40 \mathrm{mU} / \mathrm{m}^{2} \cdot \mathrm{min}$ for $180 \mathrm{~min}$ ) [13]. Muscle biopsies for measurement of O-GICNA c transferase activity were taken from vastus lateralis muscle immediately before and at the end of the insulin infusion.

Whole body insulin sensitivity, muscle biopsies. A II studies were performed at 07.30 hours after a $10-12 \mathrm{~h}$ overnight fast. Prior to study, two 18-gauge catheters were inserted, one into an antecubital vein for infusion of $20 \%$ glucose and insulin, and the second to a heated $\left(65^{\circ} \mathrm{C}\right)$ hand vein to obtain arterialized venous blood. A percutaneous muscle biopsy was obtained under local anaesthesia from vastus lateralis muscle using a Bergström needle, as previously described [9]. The muscle biopsy specimens were immediately frozen in liquid nitrogen and stored in liquid nitrogen until analysis. Immediately after the muscle biopsy, insulin (Humulin, Eli Lilly, Ind., USA) was infused in a primed-continuous manner for $180 \mathrm{~min}$. Plasma glucose was measured at 5-min intervals with a Beckman glucose analyzer (Beckman Instruments, Fullerton, Calif., U SA ), and $20 \%$ glucose was infused at a variable rate to maintain normoglycaemia. The muscle biopsy procedure was repeated at $180 \mathrm{~min}$. The two biopsies were taken from opposite legs. Enough muscle tissue was obtained from 11 of 11 NID D M and 6 of 7 normal subjects for analysis of basal 0-G IcN A c transferase activity and in 7 of 11 NID D M and 5 of 7 normal subjects for measurement of O-GICNA c transferase activity at the end of the insulin infusion. In the patients with N I D D M , normoglycaemia was reached during the second hour of the insulin infusion. Whole body glucose uptake was calculated from the glucose infusion rate required to maintain normoglycaemia during the last hour of the insulin infusion after correcting for changes in the glucose pool size [14].

$M$ aterials. Chemicals and other supplies were provided by: U D P-D - $6-\left[{ }^{3} \mathrm{H}\right]-\mathrm{N}-\mathrm{G} \mathrm{ICN} \mathrm{A} \mathrm{C} \mathrm{(specific} \mathrm{activity} 925 \mathrm{G} \mathrm{Bq} / \mathrm{mmol}$ ) (A mersham, A rlington Heights, III., USA ), R eady Protein Scintillation fluid (B eckman), O-GICNA c transferase peptide substrate (Indiana U niversity School of M edicine, D epartment of B iochemistry Biotechnology Facility, Ind., U SA ), B icinchoninic acid protein reagent (Pierce, R ockford, III., U SA ), P81 ion exchange paper (Whatman, Clifton, N.J., U SA ), other reagents, reagent grade or better (Sigma, St. L ouis, M o., U SA ).

A ssay of 0-G IcN Ac transferase activity. Tissue samples (25$50 \mathrm{mg}$ ) were homogenized in $4 \times$ volume $(\mu \mathrm{l} / \mathrm{mg})$ of homogenizing buffer containing $20 \mathrm{mmol} / \mathrm{l} \mathrm{H}$ epes, $10 \mathrm{mmol} / / \mathrm{Mg}_{2} \mathrm{Cl}_{2}$, $0.4 \mathrm{mmol} / / \mathrm{Na}_{3} \mathrm{VO}_{4}, 1 \mathrm{mmol} / \mathrm{EDTA}, 4 \mu \mathrm{mol} / /$ benzamidine, $4 \mu \mathrm{mol} / /$ phenylmethyl sulphonyl fluoride, $1 \mu \mathrm{g} / \mathrm{ml}$ pepstatin, 1 $\mathrm{ng} / \mathrm{ml}$ leupeptin and $0.5 \mathrm{ng} / \mathrm{ml}$ pepstatin and $250 \mathrm{mmol} / \mathrm{l} \mathrm{su}-$ crose (HBS), pH 7.0 in a glass homogenizer for $30 \mathrm{~s}$ on ice. The homogenate was centrifuged at $100000 \times \mathrm{g}$ for $25 \mathrm{~min}$ at $+4^{\circ} \mathrm{C}$. The supernatant was mixed with an equal volume of $30 \%$ polyethylene glycol-8000 and incubated on ice for 30 min to precipitate proteins. The precipitated material was pelleted by brief centrifugation in an E ppendorf table-top centrifuge. The supernatant was discarded and the pellet was washed once with $\mathrm{HBS}$ and resuspended in half the original volume of HBS. O-GICNAC transferase was measured as described by $\mathrm{H}$ altiwanger et al. [11] with slight modifications. 
B oth methods derive their specificity by utilizing peptide substrates that are modelled after $\mathrm{O}$-glucosaminylation motifs of known 0-G IcN A cylated proteins [11]. The method employed here utilizes an A rg-tagged peptide which binds firmly to phosphocellulose paper. Reactions were conducted in $45-\mu$ l mixtures containing 1-5 $\mu \mathrm{g}$ extract protein in $20 \mathrm{mmol} / \mathrm{l} \mathrm{H}$ epes ( $\mathrm{pH}$ 8.0) $/ 250 \mathrm{mmol} / \mathrm{l}$ sucrose $/ 5 \mathrm{mmol} / \mathrm{l}$ peptide substrate (TITSETPSSTTTQITKR) $/ 0.5 \mathrm{mmol} / \mathrm{I}$ EDTA $/ 0.2 \mu \mathrm{Ci}$ UDP$\left[6-{ }^{3} \mathrm{H}\right]-\mathrm{N}$-acetylglucosamine $(25 \mathrm{Ci} / \mathrm{mmol})$. The reactions were incubated for $60 \mathrm{~min}$ at $25^{\circ} \mathrm{C}$. A the end of the incubation $40 \mu$ portions were spotted onto $1-\mathrm{cm}^{2}$ Whatman P81 ion exchange paper. The paper squares were immediately immersed in $50 \mathrm{mmol} / \mathrm{l}$ formic acid, washed extensively with $4 \times 4 \mathrm{ml}$ $50 \mathrm{mmol} / \mathrm{l}$ formic acid per square and then transferred while still moist into scintillation vials. The samples were counted in Beckman Ready Protein scintillation cocktail ( $5 \mathrm{ml} / \mathrm{square}$ ). A II assays were conducted in the linear range for time, peptide concentration and extract protein (data not shown). Protein concentrations in muscle homogenates were measured using the bicinchoninic acid method with a kit from Pierce using bovine serum albumin as the standard.

A ssay of G FA activity. GFA activity was assayed as previously described $[8,9]$. The tissue specimen $(50-150 \mathrm{mg})$ was homogenized for $10 \mathrm{~s}$ on ice and sonicated for 10 bursts in a Branson 250 Sonifier (Branson, D anbury, Conn., U SA ) in $1 \mathrm{ml}$ of extract buffer $(100 \mathrm{mmol} / \mathrm{K} \mathrm{KCl}, 1 \mathrm{mmol} / / \mathrm{EDTA}, 50 \mathrm{mmol} / \mathrm{l}$ $\mathrm{Na}$ phosphate, $\mathrm{pH}$ 7.5). The sample was then centrifuged at $60000 \mathrm{~g}$ for $15 \mathrm{~min}$ at $+4{ }^{\circ} \mathrm{C}$ and the supernatant was used for assay of GFA activity. A II samples were assayed immediately after homogenization. We incubated $50 \mu \mathrm{l}$ of extract in a reaction mix (final volume $100 \mu \mathrm{l}$ ) containing $12 \mathrm{mmol} / \mathrm{l}$ fructose 6-phosphate, $12 \mathrm{mmol} / \mathrm{l}$ glutamine, $40 \mathrm{mmol} / / \mathrm{Na}$ phosphate (pH 7.4), $1 \mathrm{mmol} / \mathrm{I} \mathrm{EDTA}$ and $1 \mathrm{mmol} / \mathrm{l}$ dithiotreitol at $37^{\circ} \mathrm{C}$ for $45 \mathrm{~min}$ in the presence and absence of $500 \mathrm{mmol} / \mathrm{l}$ of UDP-GICNA C. The reaction was terminated with $50 \mu \mathrm{l}$ of $1 \mathrm{~mol} / /$ perchloric acid, vortexed, and centrifuged (16 $000 \mathrm{~g}$, $\left.4^{\circ} \mathrm{C}\right)$ for $15 \mathrm{~min}$. The deproteinized supernatant $(145 \mu \mathrm{l})$ was then treated with $258 \mu$ of a 1:4 mixture of tri-N-octylamine:1,1,2-trifluoroethane, vortexed and centrifuged as above for $1 \mathrm{~min}$. The aqueous phase was then filtered through a $0.2 \mu \mathrm{mol} / \mathrm{l}$ filter and $50 \mu \mathrm{l}$ was derivatized with an equal volume of 0 -phthaldialdehyde (OPA) solution (4 mg OPA dissolved in $50 \mu \mathrm{l}$ ethanol and added to $5 \mathrm{ml}$ of $0.1 \mathrm{~mol} / \mathrm{l}$ sodium borate and $10 \mu \mathrm{l}$ mercaptoethanol). Immediately thereafter samples were separated over a reverse-phase $C_{18}$ column ( $25 \mathrm{~cm} \times 4.6 \mathrm{~mm}$ Spherisorb O D S Phase Sep, N orwalk, Conn., USA ) equilibrated with $15 \mathrm{mmol} / \mathrm{l}$ sodium phosphate, $\mathrm{pH} 7.2$, $5 \%$ acetonitrile and $5 \%$ isopropanol. A bsorbance of the sample eluent was analysed using a fluorescent detector and the peak area was integrated. O PA -derivatized G IcN 6P standards were run separately to determine the retention time and to generate a standard curve to correlate area to activity. The correlation coefficient between the concentration of G IcN 6P standards and the area under the G ICN 6P peak was 0.999 or higher. The recovery of samples spiked with G ICN 6P prior to derivatization was $100 \%$. A ctivity is expressed as $\mathrm{U} / \mathrm{mg}$ protein where $1 \mathrm{U}$ represents the generation of 1 pmol of G IcN 6P/ min. The coefficient of variation of GFA measurements performed in two separate pieces of rat muscle was less than $2 \%$.

O ther methods. Plasma glucose concentration was measured in duplicate using the glucose oxidase method [15]. Serum insulin was determined before and every 30 min during the 240-min insulin infusion using a radioimmunoassay (Coat-a-Count insulin kit, D iagnostic Products Corporation, Los A ngeles, Calif., U SA ).
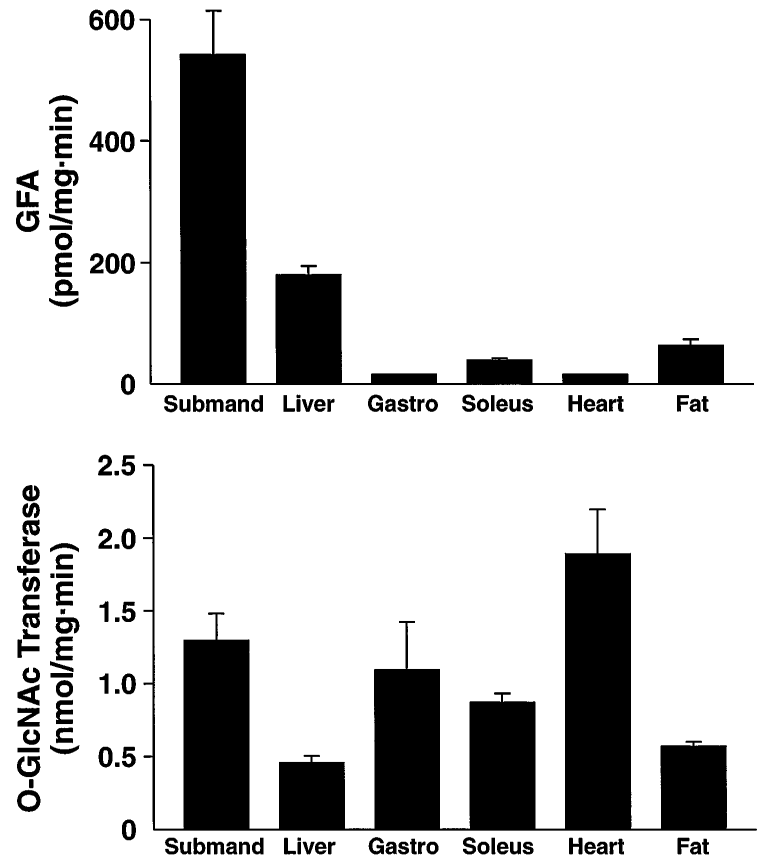

Fig. 1. Distribution of GFA (pmol/mg protein - min) and OG ICNA C transferase (nmol/mg protein - $\min$ ) activities in rat tissues ( $n=4-7$ per tissue). For significances between tissues, see text. $D$ ata represent mean \pm SE M

\section{Statistical analyses}

Enzyme activities between the groups were compared using analysis of variance followed by Bonferroni's test for pairwise comparison. Data between the study groups in the human studies were analysed using the unpaired t-test. Simple correlations between selected study variables were calculated using Pearson's correlation coefficient for normally distributed variables. M ultiple linear regression analysis was used to analyse the causes of variation in insulin sensitivity. A II calculations were made using the SY STA T statistical package (SY STA T Inc., E vanston, III., USA ). A II data are expressed as means \pm SEM .

\section{Results}

O-G ICNA c transferase and GFA rat tissues. O-G IcNA C transferase activities averaged $0.45 \pm 0.05$, $1.29 \pm 0.19,1.09 \pm 0.33,0.87 \pm 0.06,1.88 \pm 0.31$ and $0.57 \pm 0.03 \mathrm{nmol} / \mathrm{mg}$ protein $\cdot \min$ in the liver, submandibular gland, gastrocnemius, soleus, heart and adipose tissue, respectively. The activity in the liver was significantly lower than in any of the other tissues $(p<0.05$ to $p<0.001$, Fig. 1). The activities were significantly ( $p<0.05$ or less) higher in the heart, submandibular gland and soleus muscle than in adipose tissue, which had higher activity than the liver $(p<0.05)$. GFA activity was highest in the submandibular gland ( $542 \pm 60 \mathrm{pmol} / \mathrm{mg}$ protein $\cdot \min )$ followed by the liver $(194 \pm 14, p<0.001)$, adipose tissue ( $62 \pm 11, p<0.001$ vs submandibular gland and liver), 
soleus ( $39 \pm 4, p<0.001$ vs submandibular gland, liver and adipose tissue), heart ( $16 \pm 1, p<0.001$ vs submandibular gland, liver, adipose tissue and soleus), and gastrocnemius ( $15 \pm 1, p<0.001$ vs submandibular gland, liver, adipose tissue and soleus).

\section{Studies in humans}

O-G ICN A c transferase in human skeletal muscle. To assess the reproducibility of the O-GICNA c transferase measurements in human skeletal muscle specimens, duplicate biopsies were processed and assayed for 0-G IcN A c transferase on two separate days. The coefficient of variation for measurement of $0-G$ lcNA c transferase activity from two separate biopsies was $8 \pm 2 \%(n=4)$. B asal $0-G$ IcN A c transferase averaged $3.3 \pm 0.3 \mathrm{nmol} / \mathrm{mg}$ protein $\cdot \mathrm{min}$ in the normal subjects $(n=6)$. In the five subjects in whom $0-G$ IcNA c transferase was measured before and at the end of the insulin infusion, O-G IcNA c transferase averaged $3.0 \pm 0.3$ and $3.5 \pm 0.3 \mathrm{nmol} / \mathrm{mg}$ protein. $\mathrm{min}$ (NS). The coefficient of variation of O-GICNAC transferase measured before and at the end of the insulin infusion was $10 \pm 4 \%$. In patients with NIDDM, basal O-G IcN A c transferase averaged $3.8 \pm 0.3 \mathrm{nmol} /$ $\mathrm{mg}$ protein $\min (n=11)$, which was not different from that in the normal subjects. O-G ICNA c transferase was unchanged by insulin $(3.9 \pm 0.3$ vs $4.3 \pm 0.3 \mathrm{nmol} / \mathrm{mg}$ protein $\cdot \min$, basal vs insulin, NS) in seven NIDDM patients. The coefficient of variation of $0-G$ ICN A c transferase in the latter subjects was $12 \pm 3 \%$.

Insulin sensitivity. D uring the last hour of the insulin infusion ( $120-180 \mathrm{~min})$, plasma glucose $(5.1 \pm 0.1$ vs $5.0 \pm 0.1 \mathrm{mmol} / \mathrm{l}, \mathrm{NIDDM}$ vs normal subjects) and insulin ( $516 \pm 19$ vs $456 \pm 28 \mathrm{pmol} / \mathrm{l}$, respectively) were similar in both groups. The rate of whole body glucose disposal was $56 \%$ lower in the patients with NIDDM $(10.4 \pm 1.0 \mu \mathrm{mol} / \mathrm{kg} \cdot \mathrm{min})$ than in the normal subjects $(23.9 \pm 6.2 \mu \mathrm{mol} / \mathrm{kg} \cdot \min , \quad p<0.01)$. Whole body insulin sensitivity was inversely correlated with BMI $(r=-0.44, p<0.05)$ and the fasting plasma glucose concentration $(r=-0.65, p<0.005)$, but not with $0-$ G IcN A c transferase activity in either group.

\section{Discussion}

The present study was undertaken to characterize the tissue distribution and regulation of two enzymes, which are necessary for UDP-GICNAC formation and $\mathrm{O}$-linked attachment to proteins, GFA and $\mathrm{O}$ G IcN A c transferase, respectively. O-G IcN A c transferase activity was found in all insulin-sensitive tissues examined. Tissue distribution of $\mathrm{O}-\mathrm{GICNAC}$ transferase activities significantly differed from that of G FA , in keeping with tissue-specific differences in $\mathrm{N}$ - and $\mathrm{O}$-linked glycosylation. O-GICNA c transferase was also present in human skeletal muscle but its activity was not al tered by NID D M or by $3 \mathrm{~h}$ of hyperinsulinaemia suggesting that $\mathrm{O}$-linked glycosylation is a substrate-driven event.

E arly studies utilizing the colorimetric spectrophotometric assay to assess G FA found no significant activity in either heart or skeletal muscle $[16,17]$ but did find as in the present study, that GFA activity was higher in the submandibular gland than in the adult rat liver [16]. The highest G FA activities have been reported in the gut [16]. We have confirmed the latter data by measuring GFA activity in the mucosa of the duodenum and terminal ileum, in which GFA activities averaged 688 and $1128 \mathrm{pmol} / \mathrm{mg}$ protein $\cdot \mathrm{min}$, i.e. up to 75-fold higher than in skeletal muscle. B oth the submandibular gland and the gut are extensively engaged in production of mucins to which $\mathrm{N}$ acetyl-galactosamine ( $G$ alN A c) is attached via galactosyltransferase [18]. UDP-GalNA c production is also dependent upon G FA [6]. These data are consistent with the idea that mucin production is the major reason for the high GFA activity in submandibular gland and that O-G IcNA c only accounts for a small fraction of total macromolecular incorporation of labelled glucosamine [18].

In the present study GFA was measured using H PLC-detection of fluorescent glucosamine, which is more sensitive and reproducible than the colorimetric method [8-10]. In keeping with recent reports on GFA in skeletal muscle [8-10], we found GFA in skeletal muscle as well as in the heart, and found GFA to be significantly higher in soleus than in gastrocnemius muscle. A Ithough G FA activity is much lower in these tissues than in mucin-producing tissues, its activity was significantly different between several insulin-sensitive non-mucin-producing tissues. The functional significance of these differences remain to be established. In the heart, GFA activity was as high as in gastrocnemius muscle, although the heart does not exhibit glucose-induced insulin resistance in patients with IDDM [19]. In this tissue, however, glucose phosphorylation rather than glucose transport is rate-limiting for glucose uptake [20-22]. In rats, induction of insulin resistance by glucosamine is associated with a translocation defect in the insulin-sensitive glucose transporter, GLUT4 [12]. If this represents the key defect controlling glucose uptake under chronic hyperglycaemic conditions, it would not affect insulin-sensitive glucose uptake in the heart where glucose phosphorylation is rate-limiting. Whether the high GFA activity found in the liver regulates glucose uptake or merely serves to regulate U D P-G ICN A c availability for hepatic glycoprotein and glycolipid synthesis is currently unknown. 
E xcept for the liver, no data are currently available regarding O-G ICN A c transferase activity. In the present study we found significantly higher O-GICNA C transferase activity in heart, skeletal muscle and adipose tissue than in the liver. The tissue-distribution of an 0-GICNA c selective $\mathrm{N}$-acetyl- $\beta$-D-glucosaminidase, which catalyses the selective removal of U D P-G IcN A c from proteins, was also determined recently [23]. Interestingly, except for the spinal cord, the activity of this enzyme was also lowest in the liver of all rat tissues examined [23]. The functional significance of the tissue-specific differences in these enzymes are presently unknown but the finding of significant 0-G IcN A c transferase activity in many tissues is consistent with the view that attachment of G ICN A c to proteins has more in common with cellular regulation such as protein phosphorylation than with other classical types of protein glycosylation. The latter is typically extracellular and catalysed by galactosyltransferases [24]. In keeping with this, 0 GICNA C is attached to many proteins that are typically also phosphorylated and multimeric. 0-G IcN A c attachment sites are similar in amino acid sequence to growth factor kinase phosphorylation sites [25], and the expression of growth factors such as transforming growth factor $\beta$ expression can be increased via glucose-induced activation of the hexosamine biosynthetic pathway [26]. Thus, the consequences of hyperglycaemia-induced activation of the hexosamine pathway may not be restricted to glucose metabolism.

O-G IcN A c transferase activities could be reproducibly measured in human skeletal muscle. O-G IcNA C transferase activity was not altered by $3 \mathrm{~h}$ of normoglycaemic hyperinsulinaemia in normal subjects and was not different between NID D M patients and normal subjects either basally or during normoglycaemic hyperinsulinaemic conditions. A lthough no time course of insulin action on O-G IcN A c transferase activity was performed, these data imply that neither chronic hyperglycaemia (NID D M) nor acute hyperinsulinaemia was associated with changes in 0 G IcN A c transferase activity, which indicates that glucose-induced insulin resistance is mediated via mechanisms other than altered O-G IcNA C activity. These mechanisms include an increase in GFA activity in skeletal muscle, as shown by the studies performed in transgenic mice [7], and patients with NID D M [9]. A ctivation of the hexosamine pathway by glucose mass-action also seems to be involved as both acute and chronic hyperglycaemia increase levels of hexosamine metabolites in skeletal muscle [10]. Furthermore, infusion of glucosamine to rats induces insulin resistance in vivo. G lucosamine bypasses GFA and increases levels of UDP-G IcNA c in skeletal muscle [27]. Whether these alterations are accompanied by changes in 0 -linked glycosylation of specific proteins linked to down-regulation of glucose transport is currently unknown. The existence of O-GICNA c in insulin-sensitive tissues is obviously a prerequisite for such intracellular glycosylation. The present data show that O-GICNA c transferase activity is present in large quantities in tissues such as adipose tissue and skeletal muscle which are subject to glucose-induced downregulation of the glucose transport system. A s O -G IcN A c transferase activity does not itself appear to be regulated by chronic hyperglycaemia, our data would support the view that increases in hexosamine metabolites are of critical importance for the development of glucose toxicity.

A cknowledgements. We thank M s. D. Frantz and M s. M . O rtiz for excellent technical assistance, and the volunteers for their invaluable help. Supported by grants from the A merican Diabetes A ssociation (H.Y.), Finnish A cademy of Science (H.Y.), the Juvenile Diabetes Foundation and the Research Service of the Veterans A dministration (D.M.).

\section{References}

1. Y ki-Järvinen $H$, Helve $E$, Koivisto VA (1987) Hyperglycaemia decreases glucose uptake in type 1 diabetes. D iabetes 36: 892-896

2. Rossetti L, Smith D, Shulman GI, Papachristou D, DeFronzo RA (1987) Correction of hyperglycaemia with phlorizin normalizes tissue sensitivity to insulin in diabetic rats. J Clin Invest 79: 1510-1515

3. Y ki-Järvinen H (1992) Glucose toxicity. Endoc Rev 13: 415-431

4. M arshall S, B acote V, Traxinger R R (1991) D iscovery of a metabolic pathway mediating glucose-induced desensitization of the glucose transport system. R ole of hexosamine biosynthesis in the induction of insulin resistance. J Biol Chem 266: 4706-4712

5. Kornfeld R (1967) Studies on L-glutamine D-fructose 6phosphate amidotransferase. I. Feedback inhibition by uridine diphosphate- $\mathrm{N}$-acetyl-glucosamine. J B Chem 242: 3135-3141

6. Kornfeld S, Kornfeld R, Neufeld EF, O'Brien PJ (1964) The feedback control of sugar nucleotide biosynthesis in the liver. Proc N atl A cad Sci 52: 371-379

7. Hebert LF, D aniels MC, Z hou J, Crook ED, Turner R L, Simmons ST, Neidigh J L, Z hu J S, Baron A D, M cClain DA (1996) O verexpression of glutamine: fructase-6-phosphate amidotransferase in transgenic mice leads to insulin resistance. J Clin Invest 98: 930-936

8. D aniels M C, Ciaraldi TP, N ikoulina S, H enry R R, M cClain DA (1996) Glutamine: fructose-6-phosphate amidotransferase activity in cultured human skeletal muscle cells: relationship to glucose disposal rate in control and non-insulindependent diabetes mellitus subjects and regulation by glucose and insulin. J Clin Invest 97: 1235-1241

9. Y ki-Järvinen $H, D$ aniels M C , V irkamäki $A$, M äkimattila S, Defronzo RA, McClain D (1996) Increased glutamine: fructose-6-phosphate amidotransferase activity in skeletal muscle of patients with NIDD M . D iabetes 45: 302-307

10. R obinson KA , Weinstein M L , L indenmayer G E , B use M G (1995) E ffects of diabetes and hyperglycaemia on the hexosamine synthesis pathway in rat muscle and liver. D iabetes 44: 1438-1446

11. H altiwanger R S, B lomber M A, H art GW (1992) G lycosylation of nuclear and cytoplasmic proteins. Purification 
and characterization of a uridine diphospho- $\mathrm{N}$-acetyl-glucosamine: polypeptide $\mathrm{N}$-acetyltransferase. J Biol Chem 267: $9005-9013$

12. Baron A D, Zhu J -S, Z hu J-H, Weldon $H, M$ aianu L, G arvey WT (1995) Glucosamine induces insulin resistance in vivo by affecting G LUT 4 translocation in skeletal muscle. J Clin Invest 96: 2792-2801

13. R eport of a WHO Study Group (1985) D iabetes mellitus. World Health Organization Technical Report Series No 727

14. D eFronzo R A , Tobin J D, A ndres R (1979) G lucose clamp technique: a method for quantifying insulin secretion and resistance. A m J Physiol 237: E 214-E 223

15. Kadish A H, Little RL, Sternberg J C (1968) A new and rapid method for the determination of glucose by measurement of rate of oxygen consumption. Clin Chem 14: 116131

16. Richards TC, G reengard O (1973) Distribution of glutamine hexosephosphate aminotransferase in rat tissues: changes with state of differentiation. Biochim Biophys A cta 304: 842-850

17. Kaufman M , Y ip M CM , K nox WE (1971) G lucosamine-6phosphate synthesis in normal and neoplastic rat tissues. Enzyme 12: 537-544

18. Hart GW, Haltiwanger RS, Holt GD, Kelly WG (1989) Glycosylation in the nucleus and cytoplasm. A nnu Rev Biochem 58: 841-874

19. Nuutila P, K nuuti J, R uotsalainen $U$ et al. (1993) Insulin resistance is localized to skeletal but not heart muscle in type 1 diabetes. A m J Physiol 264: E 756-E 762
20. M anchester J, Kong X, Nerbonne J, L owry OH, Lawrence JC (1994) G lucose transport and phosphorylation in single cardiac myocytes: rate-limiting steps in glucose metabolism. A m J Physiol 266: E 326-E 333

21. K atz A, N yomba BL, B ogardus C (1988) No accumulation of glucose in human skeletal muscle during euglycemic hyperinsulinaemia. A m J Physiol 255: E 942-E 945

22. Y ki-Järvinen H, Sahlin K, R en J M, K oivisto VA (1990) Localization of the rate-limiting defect for glucose disposal in skeletal muscle of insulin-resistant type 1 diabetic patients. D iabetes 39: 157-167

23. D ong D, H art G W (1994) Purification and characterization of an 0-G IcNA c selective $\mathrm{N}$-acetyl- $\beta$-D -glucosaminidase from rat spleen cytosol. J B iol Chem 269: 19231-19330

24. Hart GW (1992) Glycosylation. Curr O pin Cell Biol 4: 1017-1023

25. H altiwanger RS, Kelly W G, Roquemore E P et al. (1992) G lycosylation of nuclear and cytoplasmic proteins is ubiquitous and dynamic. Biochem Soc Transact 20: 264-269

26. M cClain DA, Paterson A J, Roos MD, Wei X, Kudlow JE (1992) Glucose and glucosamine regulate growth factor gene expression in vascular smooth muscle cells. Proc $\mathrm{N}$ atl A cad Sci 89: 8150-8154

27. R ossetti L, H awkins M, G indi J, Barzilai N (1995) In vivo glucosamine infusion induces insulin resistance in normoglycaemic but not in hyperglycemic conscious rats. J Clin Invest 96: 132-140 